\title{
The Effect of Privatisation on Front Line Employees in a Service Organisation
}

\author{
F W Struwig \\ Department of Business Management, Vista University Port Elizabeth
}

\section{L van Scheers}

Department of Business Management, Vista University VUDEC

\begin{abstract}
A government organisation in the water supply business was faced with the challenge of changing their traditional way of doing business to operate as a profitdriven entity. This research focuses on how privatisation has affected front-line service employees. Both the front-line service employees and management were interviewed and included as cases to investigate changes that have occurred as a result of privatisation. These cases revealed that after privatisation front line service employees have received better training, appreciated a better system of communication, experienced a higher degree of empowerment and enjoyed an organisational culture that is more customer focused. The research, however, indicated lower levels of motivation, that employees do not appreciate an improvement in their reward system neither do they get feedback regarding their achievements and that they experience little job security.
\end{abstract}

JEL L16, 33

\section{INTRODUCTION}

This research analyses the effect of privatisation on front line service employees at a water supply organisation. The former government department was faced with the challenge of changing their traditional way of doing business to operate as a profit driven entity in the competitive market environment. The water supply organisation was faced with the challenge of shaping up to meet the service that the customer has come to expect in order to stay in business and to be ready in the face of globalisation. It is by satisfying customers that long-term success of a business can be guaranteed.

Due to the prevalent monopolistic situation in which the utility providers find themselves, rendering a quality service is an unknown phenomenon to customers. The customers have no choice but to accept this situation due to lack of 
mechanisms such as competition or effective consumer associations. Competition could be effectively achieved through privatisation of the large public enterprises.

In the next paragraphs an overview of privatisation will be given. Thereafter the components of the service triangle will be outlined. To conclude the literature review, an overview of the business to be investigated, will be given. The intention of this article is to analyse the effect that privatisation had on the front line service employees. To investigate this, data has been obtained by means of a case study from two sources, the front line employees themselves and management. Front line employees can directly comment on how privatisation has influenced them. Management was included to obtain a broader perspective of how privatisation has impacted on the front-line employees. Data analysis, conclusions and recommendations follow the discussion of the research methodology.

\section{LITERATURE REVIEW}

\section{An overview of privatisation}

Donaldson (1995: 03) defines privatisation as the transfer of ownership or control from public to private sector, which should be enough to give the private operators or owners, substantive independent power. Lane (1997: 150), like Donaldson, defines privatisation as the selling off of formerly publicly owned bodies to the private sector.

Martin and Parker (1998: 172) point out that privatisation is popularly associated with a change from a bureaucratic, sluggish and badly managed organisation to one that is dynamic, entrepreneurial and customer focused. They stress that it involves cultural change and that the change in ownership leads to increased strategic choices, which in turn implies new forms of strategic implementation.

Donaldson (1995: 126) explains that for a public enterprise to privatise, it needs to go through two phases: first it should be corporatised, then commercialised. Corporatisation is the creation of a state owned corporation by legislation. At this stage the emphasis stays with government because it is in control of the business.

Saunders and Harris (1994: 134) define commercialisation as a process directed at establishing private sector management principles, values, practices and policies within private sector organisation. Here the private sector will deliver the service while the business remains under the management of the public sector. During the pre-commercialisation phase, consumer dissatisfaction has manifested through non-payment of services. This lack of income, in turn, hindered the service 
provider's ability to maintain the infrastructure and to respond to the demand for improved or extended services.

Martin and Parker (1998: 186) argue that privatisation will lead to important changes in employment practices, including a much reduced role for trade unions as the union members change status from being ordinary workers to shareholders and focus their attention on increasing productivity and profitability. Most privatised businesses have stated their desires to cultivate a consensus around the need for commercial operation and to move away from the 'them and us' mentality. This has been promoted through training and communications programmes and by encouraging staff to own shares in the business and partake in profit sharing schemes. Employees also have increased managerial autonomy and a better remuneration.

Privatisation improves the managerial autonomy and initiatives while eliminating the political interference in the internal affairs of the business. This autonomy results in quick adoption and implementation of business principles, resulting in improved products and service (Saunders \& Harris, 1994: 66). Martin and Parker (1998: 182) state that good leadership is an important factor in the successful adaptation of a business to changes in the external environment. It is top management that must aim to provide the new strategic direction by example and by implementing organisational and other changes which signal the new culture.

Privatisation would also lead to significant changes in the organisational structure. This would involve a movement away from a bureaucratic or mechanistic and functional structure towards a more organic and decentralised form, or away from a unitary (u-form) structure to one that is more multi-form (m-form) (Martin \& Parker, 1998: 190). They also argue that, usually public sector organisations do not have the freedom that exists in the private sector to move into new areas of activity. Privatisation is an opportunity for businesses to diversify and restructure with a view to repositioning both in terms of product range and geographical location. Privatisation gives management a greater degree of freedom to develop new lines of business and close down old ones. A privatised business may use its freedom to restructure its business, diversify, merge and divest activities, and perhaps relocate operations. Saunders and Harris (1994: 55) argue that a privatised business is able to source funds from financial institutions for economically viable projects without the slow decision-making processes in government.

Donaldson (1995: 67) argues that privatisation does not benefit all people equally. There are often losers, at least in the short run especially when redundancies or loss of social assets are the key to improving efficiency and competitiveness. The short run social and political costs are often clearer than the long run overall economic 
benefits to the country, so many governments still hesitate to privatise. The political considerations involved in privatisation decisions usually require finding a way forward in which legitimate interests of effected parties are taken into account.

Saunders and Harris (1994: 53) identify other forms of involving private sector participation in improving water and sanitation service delivery such as:

\section{- $\quad$ Service contracts}

Service contracts are short-term commitments undertaken to address a shortage of a particular skill or for a specific project for which finance has been obtained. This type of service would include meter reading, design, construction of new projects, sewer cleaning and maintenance or the provision of staff for a short-term period to perform some particular function. With this contract, managerial control and funding is left with the public enterprise.

\section{- $\quad$ Management contracts}

Management contracts are similar to the service contract except that it passes certain managerial responsibilities to the contractor. The services could involve the operation of the water works plant, the training of staff or the management of a water leakage control programme. The government owns the assets but the responsibility to source financing may be shared with the private sector business. The duration of such a contract can be from 2 to 20 years. This type of contract is being used in South Africa, where government policy on privatisation is being formulated.

\section{- $\quad$ Renting of assets}

The rental (lease) contract enables the government to transfer the responsibility of operating a water or sewerage system to the private sector. Responsibility may include the full operation and maintenance of a water works plant right down to billing of customers. Such a contract is of a long duration, providing the contractor with the incentive to improve efficiency. New investments are the responsibility of government; thus this form of a contract should not be entered into without a detailed study beforehand based on a good knowledge of the system.

Customers are an obvious requirement for doing business, and the importance of customer service is emphasised by, amongst others, Harris (1996: 2). Businesses are fast realising that providing a product or service alone is not enough in today's competitive economic environment. 


\section{Customers, services and customer service}

Customers can be defined as individuals or businesses that provide revenue for your business (Jenkins, 1997: 45). Albrecht (1999: 38) defines customers as people or organisations who respond to a business presence by arriving at the doorstep ready to exchange money for goods or services. Barlow and Moller (1996: 3) on the other hand, argue that customer means not just the paying customer, but anyone who receives the benefit of goods and services, including patients in hospitals and students in schools.

Kotler (2000: 42) defines service as any act or performance that one party can offer to another that is essentially intangible and does not result in the ownership of anything. Every service or product is designed for a user. It is therefore vital for the organisation to learn about the needs of its customers so that it can deliver the relevant products and services.

Customer services are secondary activities undertaken by an organisation to maximise customer satisfaction in its primary activities (Peel, 1993: 26). These secondary activities include provision of information to customers before, during, and after sale; selling; order-taking and invoicing; packaging and presentation and finally, credit terms of payment and debt collection. According to Harris (1996: 2) customer service is anything that is done for the customer that enhances the customer experience. Harris (1996) argues that customers have varying ideas as to what they expect from customer interaction, therefore the service provider must know his or her customers, and strives to provide them with excellent customer service. Kotler (2000: 45) defines customer services as a summary of all the activities involved in making it easy for customers to reach the right parties within the business and receive quick and satisfactory service, answers, and resolutions of problems. Strong businesses are those that develop superior capabilities in this core process.

For the purpose of this research, customer service will refer to the way frontline employees receive customers and how they deal with their requirements. This includes face-to-face dealings and excludes telephone encounters.

\section{The service triangle}

The service triangle is a customer-centered model created by Albrecht (1999: 38) to emphasise the role of service systems, service strategies, and service people in a successful organisational program as indicated in Figure 1.1. 


\section{Figure 1.1 The service triangle}

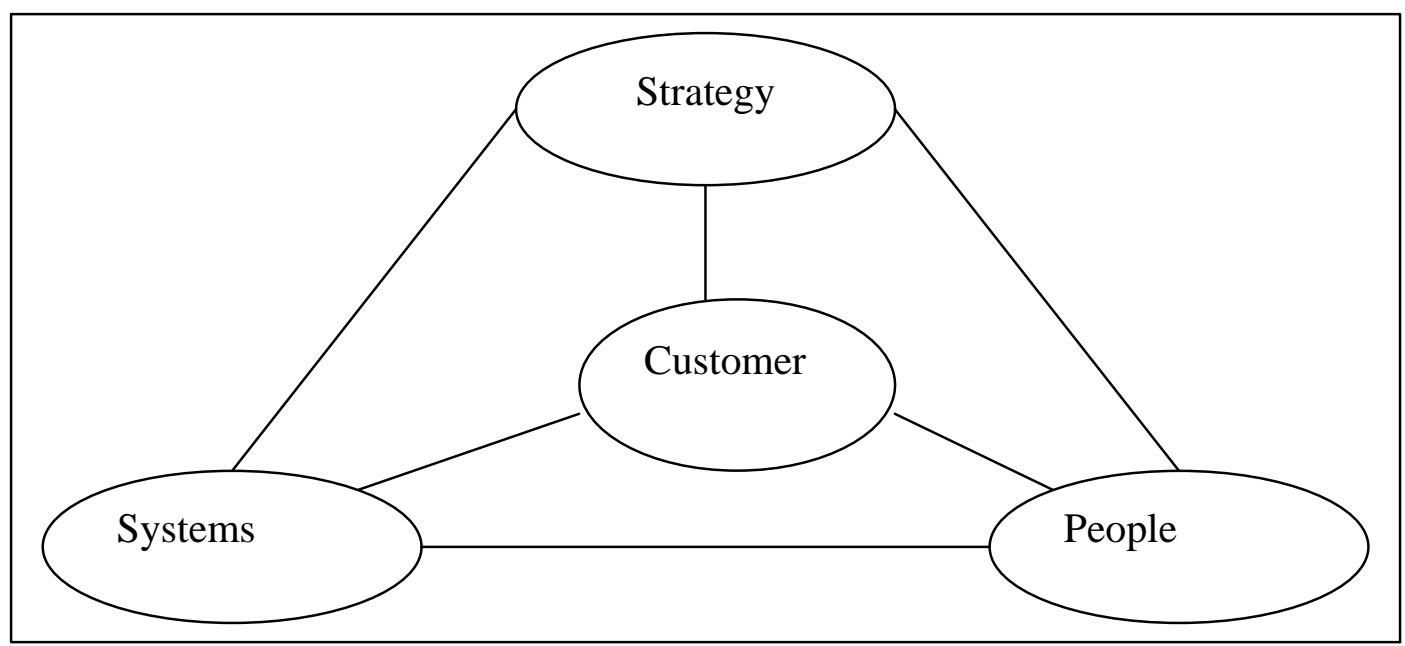

Source: Albrecht, 1999

Figure 1.1 indicates that the service triangle has four parts that are interlocked and interrelated. Each of the outer elements such as the strategy, the systems, and the people working together and separately to revolve around the most important member of the service triangle, the customer, will be discussed.

\section{Customers}

Albrecht (1999: 38) and Harris (1996: 6) identify two types of customers namely, external and internal customers. External customers are the paying customers who come to a business from the outside. They respond to the business presence by arriving at the doorstep, telephone line, or mailbox ready to exchange their money for goods or services. Internal customers are the people who work in the organisation and do business with each other. Harris (1996: 6) argues that the idea of referring to employees as internal customers gives co-workers a sense of responsibility in the customer process.

- $\quad$ The importance of internal customers

The importance of internal customers is overlooked by many businesses, particularly the small ones. Harris (1996: 7) stresses the importance to the organisation's success in providing the internal customer with the systems they need to do their work efficiently. If they do not see the importance of, for example, completing work promptly, and treating others with respect, it becomes difficult for the organisation to provide outstanding customer service to the external customers.

Any organisation that wants to serve the customer must start by making sure that the people who are "steering, fuelling, and cleaning the boat", are having their own 
needs met (Albrecht, 1999: 39). He insists that the way internal customers do business with one another affect the way they do business with the external customer. The front line service provider who can't get help from the internal customers will not be able to effectively and efficiently serve the external customer.

\section{- $\quad$ Importance of the external customer}

The importance of the external customer cannot be overemphasised. External customers bring revenue for the business. This makes them potentially the most important strategic stakeholders. The volatility of revenue levels is driven by customer demand, and understanding these issues requires an understanding of customers and the nature of their situations (Jenkins, 1997: 6). Albrecht (1999: 30) describes the external customer as the lifeblood of any organisation. Failure to notice that the health and happiness of the business relies on commerce, the exchange of money for goods and services would be a grave mistake that could see the business closing down. External customers may cost the business more to serve than is realised, as they may not be able to say what they want, or even worse, they may say one thing but behave in a totally contradictory manner (Jenkins, 1997: 14).

\section{People}

One of the outer elements in the service triangle (see Figure 1.1) is people. The service people should be the "right" people in the "right" jobs, doing the "right "things at the "right" time. Albrecht (1999: 82) argues that the best products, the best location, the cleanest rest rooms and the lowest prices won't mean anything if you've got the wrong people serving the customer.

As the service people or front line employees are the crucial link between the customer and the business, it is important to ensure that they are satisfied with their jobs. This includes amongst others employee motivation, training and development, communication and rewards.

\section{- Employee motivation}

Motivation is the willingness to exert high levels of effort toward organisational goals, conditioned by the effort's ability to satisfy some individual needs (Robbins, 1998: 168). McShane and Von Glinow (2000: 66) argue that motivation refers to the forces within a person that affect his or her direction, intensity and persistence of voluntary behaviour. They argue that motivated employees are willing to exert a particular level of effort (intensity) for a certain amount of time (persistence) and toward a particular goal (direction). Harris (1996: 84) simply defines motivation as the individual drive that causes us to behave in a particular way. It is clear from these definitions that motivation directly affects the amount of input that an 
employee is willing to put towards an organisational goal, and that the higher the level of motivation, the more the intended input.

- $\quad$ Training and development

Training and development is a means to make every employee more valuable to the business by extending their skills and knowledge, modifying attitudes towards the job and adjusting patterns of behaviour in the organisation (Pfeiffer, 1998: 76).

Given the problems with the sourcing and selection of staff, the training of front line employees must be absolutely vital. Unfortunately, organisations often appoint employees to posts with extensive face-to-face customer contact without giving them training in the necessary customer contact skills.

Nobody is born with great service skills. Service skills are a learned process, and what employees fail to pick up on their own through work experience, life experience, or on-the-job training, or in other less formal ways, the organisation has to give to them (Albrecht, 1999: 210). He advocates putting all of the front line employees through a one-day workshop that explains the language and terminology of service management. This, he argues, helps them understand their role in the organisation and gets them to think in new and creative ways about how to best serve their customers.

Frontline employees need to be trained to have the attitudes, strategies, and skills of helping, fixing, and putting the customer's needs first. According to Pfeiffer (1998: 182) training is an essential component of high performance work because organisations' success relies on frontline employees' skill and initiative to identify and resolve problems, to initiate changes in work methods, and to take responsibility for quality customer service.

Gerber, Nel and Van Dyk (1987: 75) mention that education, development and training are elements involved whenever a specific activity is undertaken to improve an employee's performance in an organisation. Training, they argue, is a deliberate effort to teach specific skills and attitudes to serve a specific purpose. Effective training is a learning experience activity, a planned business activity in response to identified needs. It is an attempt to further the goals of the organisation while simultaneously providing the opportunity for individual employees to learn and grow in the business.

A well-trained work force according to Harris (1996: 105) is one that is appropriately equipped to provide customers with excellent customer service. It is unfortunate that as time passes from the time of the original training session, some 
of the knowledge begins to be forgotten, especially if the learner did not have opportunity to use the knowledge frequently.

Training and development serves a dual role in the sense that it helps management meet its human resources requirements, while at the same time increasing the market value or marketability of those being trained. Employees are encouraged to develop themselves to their full potential in the best interests of both the business and the employee.

\section{- $\quad$ Rewarding excellent service}

Rewarding excellent customer service is a gesture of appreciation. Albercht (1999: 173) argues that most employees will appreciate any gesture of appreciation, no matter what. He points out that recognition for one's accomplishment is an important motivator, and that it should, therefore, be used extensively. Supervisors should, for example make sure that employees know that the supervisor is aware of employees' accomplishments.

McShane and Von Glinow (2000: 74) discourage the tendency by organisations to distribute the same reward, e.g. a salary increase or paid time off, to all employees with good performance. They argue that rewards that motivate some people have less effect on those with different needs. They therefore advise organisations to offer employees their choice of rewards. The result of a flexible reward system is that employees can create a reward package with the greatest value to them.

The contemporary theories, unlike the early theories of motivation such as Maslow's, warn organisations against relying too heavily on financial rewards as a source of motivation. Harris (1996) belongs to the same school of thought, and goes on to suggest several methods of encouragement that can be implemented to keep the enthusiasm of employees high. These programmes include recognition programmes such as extending the employee's lunch hour, a personal note of thanks and giving the employee corporate tickets to a special event. Albrecht (1999: 87) further suggests acknowledging the employee's contribution in the company's newsletter along with a picture. Also, to afford the employee the opportunity to express his view on an important issue such as the running of the business and daily rewards such as praise especially when they go the extra mile. He also advocates non-financial and symbolic rewards to motivate employees. "A pay cheque isn't enough; a pat on the back, a free lunch, an extra coffee break, a half-day off, or even a photo in the company's newsletter can pay huge dividends for you, the employee who receives the accolade, and the other employees around him who see that hard work, good service skills, and concern for the customer are not only important here but worthy of reward" (Albrecht 1999: 88). 
On the other hand, Freemantle (1999: 116) challenges managers to come up with innovative rewards. He argues that deciding upon a reward is a creative opportunity for a manager to demonstrate appreciation in a unique way. He goes on to suggest that to reward successful employees, there must be an element of surprise, excitement and elation, that the process must be fun, inspirational, and motivating, as opposed to a bureaucratic chore run by personnel people, e.g. employee of the month awards.

\section{- $\quad$ Positive employee attitudes}

Positive employee attitudes are a necessity in every organisation to keep customers happy and therefore see them return more business. Freemantle (1999: 20) stresses the importance of positive employee attitudes. He argues that with sensitive and courteous handling, the few customers (about 1 percent) that behave in the most atrocious way, expecting the impossible and putting extreme pressure on the highly stressed front line employees, can become reasonable. He argues that positive employee attitudes are reflected in the simple things of life: a warm smile, a friendly word, a genuine display of interest, a sensitive glance, a welcome piece of unsolicited information, a thank you. He believes that they have a magical effect on customers, yet there is nothing magical about them. He further argues that all the sins of a defective support organisation, for example, excessive delays, an erroneous bill, faulty air conditioning system, can be forgiven by a customer, with a warm smile and real initiative used by a front line person.

Keeping in mind the fact that front line employees cannot display such attitudes unless they are fully supported by the other internal customers. Management therefore has an important role in creating an environment that recognises the importance of internal customers.

\section{- $\quad$ Empowerment}

The idea of empowerment is a new approach that has significant implications in the customer service industry. As businesses continue to struggle to retain their current customers and to attract new ones, management is being challenged to look beyond traditional approaches, to empowerment, for instance.

In customer service, empowerment is to enable or permit front line employees to make a range of decisions to assist their customers (Harris, 1996: 52). Front line employees are continuously faced with customer situations that are unique to the customer and that are somewhere beyond the boundaries of existing policies. Through empowerment, front line employees are given the discretion to make decisions to assist their customers further. 
Harris (1996: 53) continues to argue that empowerment is a true opportunity since front line employees who deal with many customers frequently know the solution to the most common questions and problems. If empowered, more time is available for the supervisors and for employees to handle the more unique situations and to be thorough with all of their customers. Some utility organisations are empowering their front line employees by giving them the opportunity to hear a customer's situation and be able to grant the customer a special payment arrangement. Another way of thinking of empowerment in customer services is to empower the customer, a concept called co-production. Harris (1996) argues that customers are often willing and interested in participating in the customer service process, and that co-production works because when customers participate in the process, they have some degree of ownership over the situation and they are not only contributing to the customer service experience but also staying occupied instead of feeling like they are having to wait endlessly or are being imposed on.

\section{The service strategy}

One of the outer elements in the service triangle (see Figure 1.1) is strategy. The service strategy of a business should tell what the business is about and why it is in business or what it does for the customer (Albrecht, 1999: 79). Like Albrecht, Harris (1996: 44) argues that the most important step towards achieving excellent customer service is developing a service strategy. He argues that excellent customer service is not an accident but the result of a plan (strategy) that is well thought out. Armistead and Graham (1992: 37) add two features; clear objectives and a mission statement should accompany the strategy. The objectives set the targets for achieving the strategy, while the mission statement is a means of communicating it throughout the organisation in broad terms. The strategy and objectives may be presented within a business in a corporate business plan.

\section{The service systems}

Another of the outer elements in the service triangle (see Figure 1.1) is system. The service systems involve the way business are done and what is used to do it (Albrecht, 1999: 80). All systems must be arranged to make it easier rather than harder for the service providers to help the customers, or for the customers to help themselves. Armistead and Graham (1992: 121) argue that for a business to deliver good service consistently there must be a service delivery system, which is designed rather than just evolved, and one that is designed bearing in mind the effect it has on the customer rather than the business. The design of systems requires, amongst others, to manage the link between front line staff and back room support. 
In order to change systems and make them user-friendlier, therefore more customer-friendly, Albrecht (1999: 80) offers a few points:

- $\quad$ Change at the front line level, for the most part, should come as a result of employee consensus, not because of some high and mighty management edict;

- Sometimes its not the systems nor the way we do things that need changing, it's the people who need changing;

- $\quad$ Have a heart. Humane people management is not a contradiction in terms. Most people thrive on routine, stability and safety in their jobs, therefore drastic, overly frequent, or mindless changes should be avoided.

\section{An overview of the water supply business under investigation}

The water supply business was officially established in 1994. It took over the functions of an abolished government department. Its main function is to provide water and sewerage services in the country. Before commercialization, the government department was not run as effectively and efficiently as necessary. The demand on existing resources was too great and there was a need for rapid expansion of areas of supply and responsibility. Failures were becoming apparent in the form of major water losses and disruptions of service due to the bursting of ageing pipes. The effluent from the wastewater treatment plants did not comply with the discharge standards prescribed by law. There were frequent water shortages in the low-veld, an area of the country that receives less rainfall. The quality of water needed improvement, and clearly, there was a need for the board to reduce the cost of the service.

Customer care was perhaps totally absent and consumer dissatisfaction was manifested through non-payment of services. This lack of income, in turn, hindered the service provider's ability to maintain the infrastructure and to respond to the demand for improved or extended services. The estimated capital cost of remedying these deficiencies varied between R 0.5 billion and R1 billion over a tenyear period. Clearly, this amount of capital could not be supplied from government sources alone and not from financial markets unless the government department was operating efficiently and cost effectively, and the ability to recover costs was demonstrated. This called for commercialisation!

After commercialisation, the business was faced with the challenge of changing their way of doing business to operate as a profit driven entity in the competitive market environment. To succeed in this endeavour, a focus on customer 
commitment cannot be over emphasised. As mentioned earlier, privatisation could bolster the customer service focus.

The business appointed a new board of directors and is presently implementing a newly adopted strategic plan. Whilst this is encouraging, there are limitations to this business in that government still has to make major policy decisions on retrenchments and sourcing of finance. The decisions to restructure has to have government approval and it cannot diversify or enter into mergers as the Water Corporation Act of 1994 limits the business operations to water and sanitation.

The business investment increased from R15 million to R43 million for the year $2000 / 2001$ as a result of the implementation of projects that are outlined in the corporate plan of 1998 to 2003. The Government, the World Bank and business itself provided funds for the projects. The business had a net loss of R3.2 million for the 2000/2001 financial year. This loss was attributed to an increase in operating costs, loss of revenue as a result of closure of some major customers in the main industrial sites plus an increase in the cost of capital due to loan financing.

The business plans to achieve excellence in the quality of service to its customers, meeting and exceeding customer expectations, by developing functions, roles and responsibilities for its employees, supported by appropriate technology and setting of standards which will reflect customers' needs and expectations. Its objectives are to:

- $\quad$ Establish higher levels of customer satisfaction;

- $\quad$ Establish higher levels of employee satisfaction;

- Create enabling conditions for the overall contribution to improved performance of the business.

The level of customer service or customer care clearly needs to be afforded some attention. The organisation's attitude to customer needs is reminiscent of the past years, when people believed that the sole purpose of business was to make profit, when customers were a necessary inconvenience required to achieve this profit goal.

It is only by satisfying the customers that you can guarantee the long-term success of your business. This business clearly has to address its customers' needs and expectations to remain viable and this research will address this aspect. 


\section{RESEARCH METHODOLOGY}

As the aim of this research is to investigate the effect of privatisation on front-line employees, a qualitative research method was employed. A case study method of research design has been selected for this research. It is dynamic and sensitive in capturing the complexity of action in the environment. The case study explores and probes in depth the circumstances of the organisation and the relation between organisational behaviour and its specific context.

\section{Population and samples}

A population is the study object, which may be individuals, groups, organisations, human products and events, or the conditions to which they are exposed (Welman \& Kruger, 1999: 18). Saunders, Lewis and Thornhill (2000: 150) define a population as the full set of cases from which data can be sourced. Cooper and Schindler (2001: 769) on the other hand, define a population as the total collection of elements about which we wish to make some inferences. To collect information covering all aspects of the research question, data is sourced from two population groups. These are:

- $\quad$ The front line employees, and

- Senior Management of the organisation.

The total population of the front line employees was used as cases, because it is a small population of thirteen staff members. This population was purposely selected because these are employees that are directly and constantly in contact with the customers.

In selecting the senior managers to include as cases, purposive sampling was used. Three directors were interviewed to gather information pertaining to the business and functional strategies on customer service. They include:

- Director-Operations, who is in charge of existing systems and managing the project teams

- $\quad$ Director-HR, who is responsible for developing the skills required for employees, including the front line employees

- $\quad$ Managing Director, to get a feel of where the corporation will be in the next 5 years.

The Public Relations Officer was also interviewed to gather further information on customer perceptions of the business. 


\section{Data collection methods}

A structured questionnaire was used during the interviews with the front line employees and senior management. Relevant organisational and managerial records, the policies, and procedures of the water supply organisation were also scrutinised. This was done to provide insight into the type of problems that existed in the organisation in terms of what the policies and procedures stipulated. This facilitated the compilation of the questionnaire used in the structured interviews. Expert opinion was then sought to ensure the validity of the items included in the questionnaire (Struwig \& Stead, 2001: 139).

To ensure reliability in collecting data, special care was taken by the researcher to clearly explain the aim of the study to all respondents and ensure the confidentiality of their responses to the questions asked. This was done to enable the respondents to answer questions with honesty and objectivity.

The research methodology provided a solid background to ensure that an in-depth analysis of the research problem could be made.

\section{RESEARCH RESULTS}

The research results of the frontline employees on the evaluation of the components of the service triangle and interviews with management are outlined in the next paragraphs.

\section{Results of the front line employees}

The results of the front line employees' evaluation of the components of the service triangle, before and after privatisation, are provided in Figure 1.2.

The employees' evaluation of the components of the service triangle as depicted in Figure 1.2 revealed the following:

\section{- $\quad$ Service people}

Figure 1.2 shows that employees appreciate an improvement after privatisation, in all the components, except in rewards. Front line employees are also more motivated than before privatisation, receive more or better training, and appreciate a better system of communication in the organisation, a higher degree of empowerment and an organisational culture that is more customer-focused. It could be that employees do not appreciate an improvement in rewards because the 
executives and professionals are enjoying a much higher improvement in rewards after privatisation than themselves.

\section{Figure 1.2 The results of front line employees' evaluation of the components of the service triangle (before and after privatisation)}

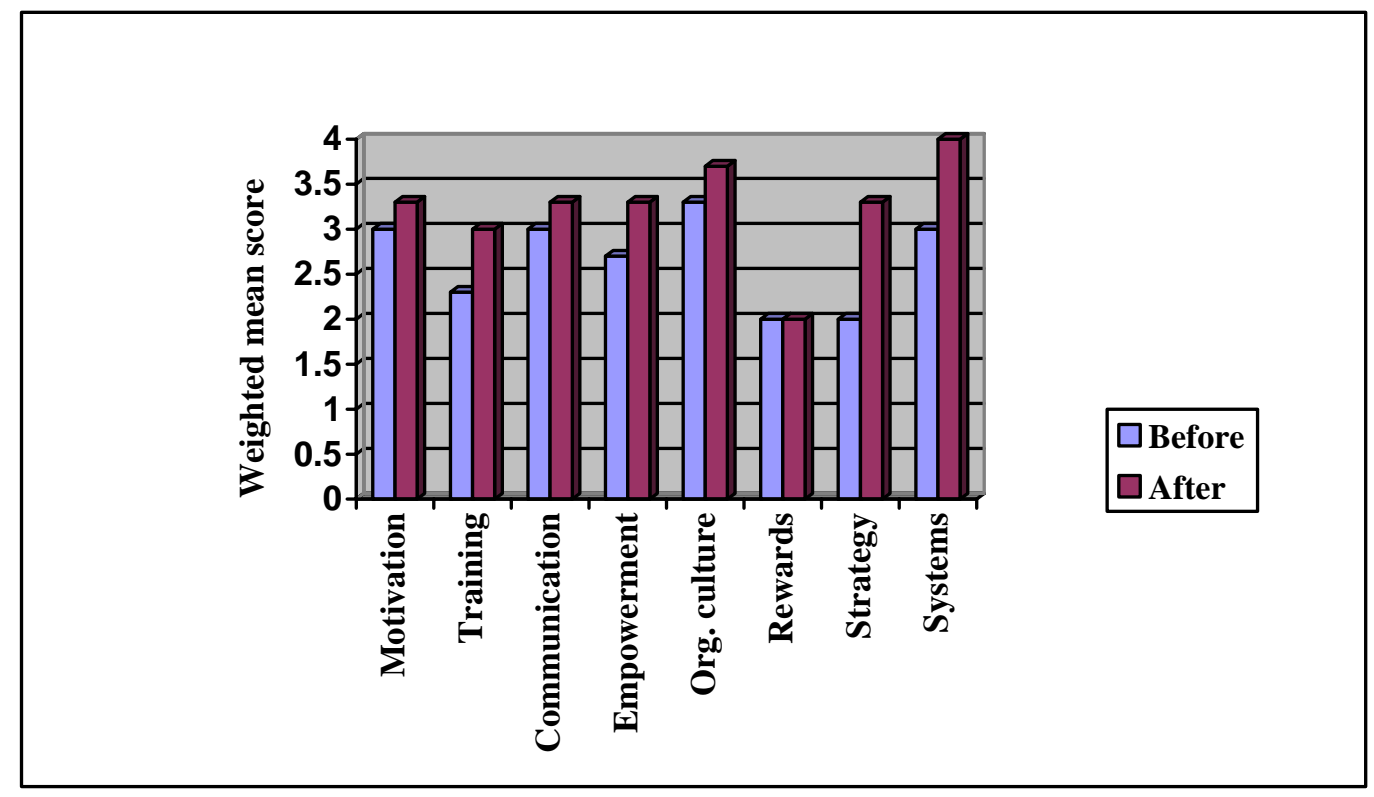

Figure 1.2 further reveals a low improvement in motivation and communication levels since privatisation. Though changes may be positive, they are rather small. Management must rise to the challenge to make meaningful improvements to these components.

Further investigation on why the improvement in the two issues was so low, revealed that front line employees were motivated by public recognition before privatisation. The majority of respondents also believe that management does not give them feedback regarding their success and that they have little job security. Nonetheless, the respondents feel that they are in the right job. This could be attributed to the fact that they have been trained only for this and no other job.

- $\quad$ A service strategy and system

Figure 1.2 indicates an improved customer service strategy and an improvement in service systems after privatisation. The improvement in these two components is, according to the employees, the most remarkable (largest improvement) since privatisation. 


\section{Results of the analysis of the responses of senior management}

The interviews with management were aimed at verifying the information obtained from employees. The aim of the interview with the assistant networks engineer was to gather information on changes in technology that have been put in place after privatisation, to address customer problems. For each customer problem put to him, the engineer first explained in detail exactly what the problem is or what it entails, and its causes, before explaining how the problem is addressed. It should be noted that management made extensive changes in support of its strategy to be customer focused. Clearly, a lot of money has been invested in this exercise.

The aim of this interview with the public relations manager was to establish if management has formulated a customer service strategy, and if so, whether there are systems in place to support the strategy.

The main responses include that the organisation does have a customer services strategy, which is part of the overall strategy. It involves the decentralisation of operations in order to speedily and efficiently communicate customer problems, discuss them, make the necessary decisions, and implement them at regional level without involving headquarters.

It was interesting to find that there are no major differences in the responses given by the public relations officer and the front line employees. They both acknowledged that a customer service strategy does exist, that employees are effectively informed of changes in the organisation, and that front line employees are trained to deal with customer problems effectively. However, employees are not as positive as management that they are indeed empowered. Such discrepancies are normal since there are varying degrees of empowerment. One has to probe deeper to find out the extent of employee empowerment, and the extent of its adequacy.

According to senior management the front line employees give feedback to the revenue administrator on a daily basis. Discussions are held to analyse customer problems and come up with viable solutions. The organisation does indeed convert customer complaints to opportunities. Classical examples include complaints on pipe breakages, brown or "dirty" water in a given area, unexplained high meter readings, and reduction in water pressure. The organisation does indeed have adequate systems in place to support the customer service strategy. It has increased investment on machinery after privatisation in order to facilitate the change from a previously labour intensive to a technology-intensive system. The organisation now has access to a wider range of sources of finance than when it was totally 
under government. Senior management provided examples of newly acquired technology.

There are no rewards awarded for outstanding performance. The organisation is, however, working on establishing annual performance related awards, which will be team based towards the lower end of the corporate ladder.

The perceptions of the managers are not different from those of the employees themselves. Both parties acknowledge that customer complaints are indeed converted to opportunities, that employees do give feedback on customer problems, that there are adequate service systems to support the service strategy, and that there are no rewards for outstanding performance at present. It is also encouraging that management has plans in the pipeline to introduce rewards for outstanding performance.

\section{CONCLUSIONS}

This case study aimed to analyse the effect that privatisation had on front line employees. The level of motivation in the front line employees is unsatisfactory, even though it has improved somewhat since privatisation. The research conducted, confirmed that motivation is an essential component of high performance work because an organisations' success relies on frontline employees' skill and initiative to identify and resolve problems, to initiate changes in work methods, and to take responsibility for quality customer service.

The research also indicated that front line employees received better training, appreciated a better system of communication and received a higher degree of empowerment since privatisation. The research further established that employees do not appreciate an improvement in rewards because the executives and professionals are enjoying a much higher improvement in rewards after privatisation than they are. The majority of respondents also believe that management does not give them feedback regarding their success and that they have little job security. Nonetheless, the respondents feel that they are in the right job. This could be attributed to the fact that they have been trained only for this and no other job.

Interviews with management revealed that the organisation has a customer services strategy that involved the decentralisation of operations in order to speedily and efficiently communicate customer problems. Changes in the organisation are communicated to employees through written memos and circulars that are personally circulated by supervisors. Front line employees are empowered to take decisions up to a certain level and trained to deal with customer problems 
effectively. Lastly, the research established that there are no rewards for outstanding performance of employees at present.

\section{RECOMMENDATIONS}

This case study aimed to analyse the effect that privatisation had on front line employees. The research recommends the following:

- Improving the employees' working conditions, rewards, or training and developing them can improve employee attitudes.

- $\quad$ Management is advised to provide adequate training and development for its front line staff. Training and development is vital to any organisation because it is a means to make every employee more valuable to the enterprise by extending skills and knowledge, modifying attitudes towards a job and adjusting patterns of behaviour in the organisation. Inadequately trained front line staff can make customers lose confidence in the organisation or customers may hit back at the organisation by refusing to pay their bills timeously, thereby causing cash flow problems. Furthermore, training and development serves a dual purpose in the sense that it helps management meet its human resources requirements, while at the same time increasing the market value of those being trained. This translates into higher levels of motivation.

- $\quad$ Management needs to improve employee motivation. Motivation directly affects the amount of input that an employee is willing to put towards an organisational goal, and that the higher the level of motivation, the more the intended input. As with employee attitudes, employee motivation can be improved by improving the employees' working conditions, rewards, or training and development.

- Recognition of accomplishments is an important motivator. Management is advised to offer more rewards to customer services staff and further, to offer different rewards for excellent service to deserving candidates.

- Management is advised to foster a culture that recognises the importance of internal customers. The way the internal customers do business with one another affects the way they do business with the external customers. If the front line staff cannot get help from the internal customers, they will not be able to effectively and efficiently serve the external customer. 
- $\quad$ Empowering customer service providers benefits everyone: customers don't have to wait long while their situation is explained to a supervisor, the supervisors are left to do more important work, and the customer service staff is motivated to do their work.

- Management's efforts to provide the necessary systems to support the service strategy are visible. The Global Information system (GIS) has improved the efforts to locate customer meters, the computerisation of the customer service centers (revenue offices), the upgrade of the fault reporting system, etc. Good service systems alone will not be enough. Management must also focus on improving the other unsatisfactory factors, such as motivation, rewards, empowerment, training etc.

\section{REFERENCES}

1 ALBRECHT, S. (1999) Service, Service, Service. The Growing Business' Secret Weapon, Bob Adams Inc.: Massachusetts

2 ARMISTEAD, C. \& GRAHAM, C. (1992) Customer Service \& Support. Implementing Effective Strategies, Pitman Publishing: London.

3 BARLOW, J. \& MOLLER, C. (1996) A Complaint is a Gift, BerrettKoehler Publishers: San Francisco.

4 COOPER, J. \& SCHINDLER, D. (2001) Business Research Methods, McGraw Hill: Boston.

5 DONALDSON, D. (1995) Privatisation. Principles and Practice, The World Bank and International Finance Corporation: Washington D.C.

6 FREEMANTLE, D. (1999) Incredible Customer Service, McGraw-Hill: London.

7 GERBER, P. D., NEL, P. S \& VAN DYK, P.S. (1987) Human Resources Management, Southern Book Publishers: Pretoria.

8 HARRIS, E. (1996) Customer Service. A practical Approach, PrenticeHall: New Jersey.

9 JENKINS, M. (1997) The Customer Centred Strategy, Pitman Publishing: London.

10 KOTLER, P. (2000) Marketing Management Analysis, Planning, Implementation \& Control (9th ed.) Prentice-Hall: New Jersey.

11 LANE, J. (1997) Public Sector Reform. Rationale, Trends and Problem, SAGE Publications: London.

12 MARTIN, S. \& PARKER, D. (1998) The Impact of Privatisation, Routledge: London.

13 MCSHANE, S. \& VON GLINOW, M. (2000) Organisational Behaviour, McGraw Hill: Boston. 
14 PEEL, M. (1993) Customer Service: How to Achieve Total Satisfaction, Kogan Page: London.

15 PFEIFFER, J. (1998) The Human Equation: Building Profits by Putting People First, Harvard Business School Press: USA.

16 ROBBINS, S. (1998) Organisational Behaviour (8th ed.) Prentice Hall: New Jersey.

17 SAUNDERS, P. \& HARRIS, C. (1994) Privatisation and Popular Capitalism, Open University Press: Buckingham.

18 SAUNDERS, M., LEWIS, P. \& THORNHILL, A. (2000) Research Methods for Business Students (2nd ed.) Prentice Hall: London.

19 STRUWIG, F.W. \& STEAD, G.B. (2001) Planning, Designing, and Reporting Research, Pearson Education: Cape Town.

20 WELMAN, J. \& KRUGER, S. (1999) Research Methodology for the Business and Administrative Sciences, Oxford University Press: Cape Town.

21 ZWANE, Z. (2000) 'The effect of privatisation on customer services at Swaziland Water Services Corporation (SWSC)', Unpublished MBA dissertation, Milpark Business School, Johannesburg. 